\title{
KARAKTERISTIK FISIKOKIMIA DAN PROFIL SENSORI MANGGA GEDONG PADA DUA TINGKAT KEMATANGAN
}

\author{
[Physicochemical Characteristics and Sensory Profile of Gedong Mango at \\ Two Different Maturity Levels]
}

\author{
Mutiara Utami ${ }^{1)}$, Christofora Hanny Wijaya ${ }^{2) \star}$, Darda Efendi ${ }^{3)}$, dan Dede Robiatul Adawiyah ${ }^{2)}$ \\ 1) Program Studi Magister IImu Pangan, Sekolah Pascasarjana, IPB University, Bogor \\ 2) Departemen Ilmu dan Teknologi Pangan, Fakultas Teknologi Pertanian, IPB University, Bogor \\ ${ }^{3)}$ Departemen Agronomi dan Hortikultura, Fakultas Pertanian, IPB University, Bogor
}

Diterima 13 Mei 2020 / Disetujui 18 Agustus 2020

\begin{abstract}
Mangoes of Gedong variety (Mangifera indica L. var. gedong) is one of the exported commodities from Indonesia. Half mature mangoes of this type are called gedong mangoes, whereas the full ripe mangoes are called gedong gincu mango. This research aimed to determine the physicochemical characteristics, sensory attributes and volatile compounds of the above two mango types. The results showed that gedong mangoes had a lower $\mathrm{pH}$ value, less total soluble solid, harder texture, and the skin color had a lower intensity of lightness, redness, and yellowness as compared to gedong gincu mango. The sensory analysis using rate-all-that-apply (RATA) method showed that attributes of color, fibrous, aroma (fruity, caramel, cooked, green, fermented, floral, sweet), taste (sweet, sour), melting, firmness, juiciness and astringency were significantly different between gedong and gedong gincu mango. The overall sensory of gedong gincu mangoes was more preferred by the panelists with the hedonic score of $6.20 \pm 0.09$ ( $6=$ like) while that of gedong mango was $5.37 \pm 0.09$ ( $5=$ slightly like). The sensory profiles of both mangoes were supported by the analysis of their volatile compounds. The gedong mango had predominantly green type of volatiles aroma while the gedong gincu was dominated by the fruity sweet ones. The sensory acceptability of gedong gincu mango was significantly higher rather than that of gedong mango.
\end{abstract}

Keywords: gedong mango, physicochemical characteristic, rate-all-that-apply, sensory profile, SPME

\begin{abstract}
ABSTRAK
Buah mangga varietas gedong (Mangifera indica L. var. gedong) merupakan salah satu komoditas buah ekspor dari Indonesia. Buah mangga gedong adalah buah dengan kematangan half mature (setengah matang), sedangkan buah yang telah mencapai tingkat kematangan full ripe (matang) disebut buah mangga gedong gincu. Penelitian ini bertujuan untuk menentukan karakteristik fisikokimia, atribut sensori dan komponen volatil dari buah mangga pada 2 tingkat kematangan tersebut. Hasil penelitian menunjukkan bahwa buah mangga gedong memiliki nilai $\mathrm{pH}$ yang lebih rendah, total padatan terlarut yang lebih kecil, tekstur daging buah yang lebih keras, dan warna kulit buah yang lebih rendah intensitas kecerahan, warna merah serta warna kuningnya bila dibandingkan dengan buah mangga gedong gincu. Analisis sensori menggunakan metode rate-all-that-apply (RATA) menunjukkan bahwa atribut sensori: warna, berserat, aroma (fruity/aroma buah-buahan, caramel/aroma karamel, cooked/aroma buah matang, green/aroma buah mentah, fermented/aroma terfermentasi, floral/aroma bunga, sweet/aroma manis), rasa (manis, asam), melting (daya leleh), firmness (kukuh, teguh), juiciness (berair) dan astringency (sepat) berbeda secara signifikan pada buah mangga dengan 2 tingkat kematangan. Penerimaan sensori secara kese-

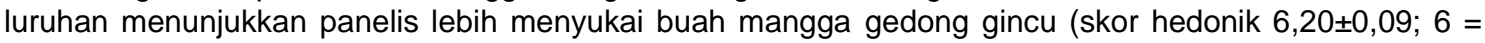
suka) dibandingkan dengan buah mangga gedong (skor hedonik $5,37 \pm 0,09 ; 5=$ agak suka). Profil sensori dari buah mangga dengan 2 tingkat kematangan tersebut didukung oleh hasil analisis komponen volatil aromanya. Buah mangga gedong didominasi oleh komponen volatil aroma yang memiliki aroma green (aroma buah mentah) sedangkan buah mangga gedong gincu oleh komponen volatil beraroma fruity, sweet (aroma buah-buahan, aroma manis).
\end{abstract}

Kata kunci: karakteristik fisikokimia, mangga gedong, profil sensori, rate-all-that-apply, SPME

*Penulis Korespondensi:

E-mail: channywijaya@apps.ipb.ac.id 


\section{PENDAHULUAN}

Buah mangga varietas gedong (Mangifera indica L. var. gedong) merupakan salah satu buah komoditas ekspor dari Indonesia. Buah mangga varietas gedong dipanen saat mencapai tingkat kematangan setengah matang (half mature) yaitu < 108 HSBM (disebut buah mangga gedong) dan matang (full ripe) yaitu 109-120 HSBM (disebut buah mangga gedong gincu) (Sari et al., 2016). Sentra produksi buah mangga gedong yaitu di provinsi Jawa Barat, Jawa Timur, dan Nusa Tenggara Barat. Secara fisik, buah mangga gedong umumnya berukuran $6-15 \mathrm{~cm}$, bentuk buahnya bulat, serta memiliki berat mencapai 200-300 g. Buah mangga gedong memiliki warna kulit hijau. Selama proses pematangan, warna kulit buah berangsur-angsur berubah menjadi kuning kemerahan dan disebut buah mangga gedong gincu.

Tingkat kematangan menjadi salah satu faktor terpenting dalam perdagangan buah mangga. Buah mangga gedong diperdagangkan ke negara dengan jarak yang jauh (Fahri et al., 2016) dan dipanen saat buah matang (mature) tapi belum masak (ripe). Selama proses transportasi, buah mangga mengalami perubahan cita rasa sehingga mencapai kualitas penerimaan konsumen. Hal ini karena buah mangga digolongkan sebagai buah klimakterik yang mampu melanjutkan proses pematangan setelah buah dipanen dari pohon induknya (Siriamornpun et al., 2017). Penerimaan konsumen terhadap buah mangga ditentukan oleh penampakan buah, kesegaran, warna, tekstur, rasa, dan aroma. Karakteristik ini digunakan untuk mengevaluasi kualitas dan tingkat kematangan dari buah mangga (White et al., 2016).

Selama proses pematangan, dibebaskan banyak komponen volatil dari buah mangga yang memengaruhi kualitas aroma buah mangga matang. Komponen volatil dari buah mangga juga dipengaruhi oleh kultivar serta letak geografis buah (Li et al., 2017; Munafo et al., 2014). Komponen volatil yang terkandung dalam buah mangga telah banyak dipelajari melalui berbagai metode pemisahan. Proses memisahkan komponen volatil dari suatu bahan pangan memiliki tingkat kesulitan tertentu. Hal ini karena komponen tersebut memiliki tingkat volatilitas tinggi dengan konsentrasi yang rendah dalam matriks pangan. Metode pemisahan komponen volatil yang digunakan pada penelitian ini yaitu dengan metode solid-phase microextraction (SPME). Penggunaan metode SPME dianggap cepat, sederhana, sensitif, dan tidak menggunakan pelarut (Liu et al., 2020).

Salah satu upaya untuk meningkatkan kualitas buah mangga varietas gedong adalah dengan mengembangkan pengetahuan mengenai profil cita rasa pembentuk buah mangga. Informasi terkait sifat fisikokimia, profil sensori, serta komponen volatil pembentuk aroma buah mangga menjadi penting sebagai dasar untuk memperoleh profil mutu buah mangga secara utuh. Tujuan penelitian ini adalah untuk mendapatkan karakteristik fisikokimia dan atribut sensori penciri dari buah mangga varietas gedong pada dua tingkat kematangan yang berbeda.

\section{BAHAN DAN METODE}

\section{Bahan}

Buah mangga varietas gedong (Mangifera indica L. var. gedong) didapatkan dari petani lokal di Cirebon, Jawa Barat dengan dua umur buah yang berbeda yaitu buah mangga gedong dengan umur buah 88 hari dan buah mangga gedong gincu dengan umur buah 110 hari setelah bunga mekar (HSBM). Informasi mengenai umur buah diperoleh dari petani lokal tanpa melakukan penandaan pada bunga mangga (tagging). Warna kulit buah mangga gedong adalah hijau dan buah mangga gedong gincu adalah kuning dengan semburat kemerahan. Buah mangga gedong dan gedong gincu memiliki bentuk bulat dengan tekstur keras untuk Gedong dan agak lunak untuk gedong gincu. Buah mangga gedong dan gedong gincu memiliki kisaran berat 200-260 g. Contoh dari buah mangga gedong dan gedong gincu pada penelitian ini ditunjukkan oleh Gambar 1.

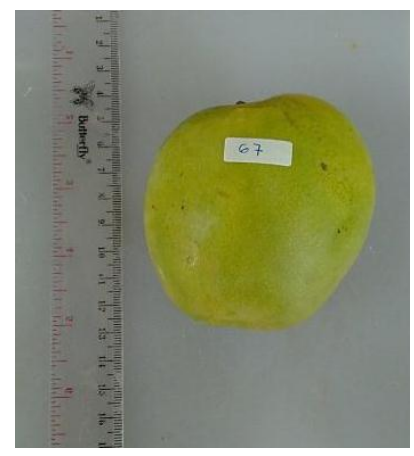

A

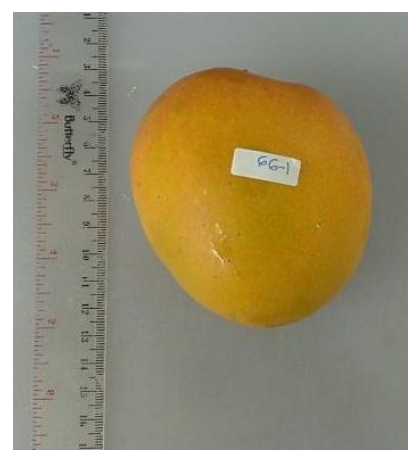

B
Gambar 1. Penampakan buah mangga gedong $(A)$ dan gedong gincu (B), 4 hari setelah pemanenan

\section{Persiapan sampel}

Buah mangga gedong diambil dari 4 pohon sedangkan buah mangga gedong gincu diambil dari 5 pohon. Sebanyak 35 buah mangga gedong dan 35 buah mangga gedong gincu kemudian dikumpulkan untuk disortasi dan dibersihkan untuk menghilangkan getah dan kotoran yang menempel pada kulit. Sebanyak 29 buah mangga gedong dan 34 buah mangga gedong gincu hasil sortasi kemudian di- 
susun kedalam peti kayu berongga yang sudah dilapisi dengan kertas karton yang dilubangi untuk dibawa ke laboratorium menggunakan mobil pada kondisi suhu ruang $\left(20-25^{\circ} \mathrm{C}\right)$. Setelah buah tiba di laboratorium, kembali dilakukan sortasi untuk memisahkan buah yang rusak dan memar selama proses transportasi. Sebanyak 27 buah mangga gedong dan 27 buah mangga gedong gincu didapatkan kemudian buah dipisahkan untuk analisis fisikokimia, analisis sensori, dan analisis komponen volatil. Analisis fisikokimia dilakukan pada hari ke empat setelah panen, sementara analisis sensori dilaksanakan pada hari ke enam setelah panen, dan analisis komponen volatil dilakukan 10 hari setelah panen. Buah mangga gedong dan gedong gincu disimpan dalam refrigerator (suhu $4^{\circ} \mathrm{C}$ ) dengan dibungkus sebagian menggunakan kertas koran hingga digunakan untuk analisis.

\section{Analisis total asam tertitrasi (TAT) (AOAC, 2012)}

Analisis total asam tertitrasi (TAT) dilakukan menggunakan 3 buah mangga gedong dan 3 buah mangga gedong gincu, yang masing-masing dihancurkan dengan blender (Sharp tipe SB-TW101P, Cina) secara terpisah. Analisis total asam tertitrasi (TAT) dilakukan dengan mentitrasi sebanyak 100 $\mathrm{mL}$ pure sampel dengan $\mathrm{NaOH} 0,1 \mathrm{~N}$ (Merck Indonesia), triplo. Tiap sampel sudah ditetesi 3-5 tetes indikator phenolphthalein (pp). Volume dari $\mathrm{NaOH}$ yang digunakan hingga larutan sampel mengalami perubahan warna dicatat dan dilakukan perhitungan berikut:

Total Asam $=\frac{\mathrm{mL} \mathrm{NaOH} \times \mathrm{N} \mathrm{Fp} \times \mathrm{mr} \mathrm{NaOH}}{\mathrm{mg} \mathrm{sampel}} \times 100 \%$

\section{Pengukuran pH (Zainal et al., 2017)}

Pengukuran $\mathrm{pH}$ dilakukan terhadap 3 buah mangga gedong dan 3 buah mangga gedong gincu, triplo, yang masing-masing diblender secara terpisah. Pengukuran dilakukan menggunakan $\mathrm{pH}$ meter dengan alat 700 Eutech Instruments (Thermo Fisher Scientific Inc, USA).

\section{Analisis total padatan terlarut (TPT) (AOAC, 2012)}

Analisis total padatan terlarut (TPT) dilakukan terhadap 3 buah mangga gedong dan 3 buah mangga gedong gincu, triplo, yang masing-masing diblender secara terpisah, dengan pengukuran menggunakan Abbe Refractometer (Spectronic Instruments) (Thermo Fisher Scientific Inc, USA). TPT terbaca langsung pada layar refractometer dalam satuan ${ }^{\circ}$ Brix.

\section{Analisis warna (AOAC, 2012)}

Analisis warna dilakukan pada permukaan kulit buah dan daging buah mangga ( 3 buah mangga gedong dan 3 buah mangga gedong gincu, triplo) menggunakan alat chromameter Hunter L, a, b (Minolta CR-300/CR-310, Jepang).

\section{Pengukuran firmness (Nassur et al., 2015)}

Pengukuran firmness daging buah mangga (3 buah mangga gedong dan 3 buah mangga gedong gincu, triplo) dilakukan menggunakan alat penetrometer dengan $8 \mathrm{~mm}$ probe (load cell $50 \mathrm{~kg}$; Digital Penetrometer) (Precision Scientific Petroleum Company L.P, USA).

\section{Analisis profil sensori citarasa buah mangga gedong dan gedong gincu (Ngamchuachit et al., 2015; Ares et al., 2014)}

Profil sensori buah mangga gedong dan gedong gincu dilaksanakan berdasarkan Keterangan Lolos Kaji Etik (Ethical Approval Nomor: 109/IT3. KEPMSM-IPB/SK/2018) pada 09 Oktober 2018 oleh Komisi Etik Penelitian yang Melibatkan Subyek Manusia LPPM IPB. Profil sensori citarasa buah mangga gedong dan gedong gincu dianalisis menggunakan uji sensori metode rate-all-that-apply (RATA) (Ares et al., 2014) yang mampu mengukur intensitas atribut sensori yang berkontribusi pada buah mangga. Metode RATA menggunakan 100 orang panelis tidak terlatih (usia 20-51 tahun; 74 perempuan dan 26 laki-laki) yang merupakan akademisi dan mahasiswa dari Departemen IImu dan Teknologi Pangan (ITP), Kampus IPB Dramaga, Bogor. Panelis diminta untuk memberikan penilaian terhadap intensitas atribut sensori dari buah mangga gedong dan gedong gincu. Atribut sensori yang dinilai intensitasnya diambil berdasarkan studi literatur buah mangga, yaitu atribut penampakan, aroma, rasa, tekstur, dan aftertaste (sisa rasa) (Tabel 1). Apabila panelis tidak dapat merasakan adanya atribut sensori pada sampel, maka panelis memberikan tanda centang $(\checkmark)$ pada kolom tidak dapat dirasakan. Evaluasi atribut sensori untuk setiap sampel menggunakan 5 skala ordinal, yaitu skala 1 menunjukkan intensitas atribut sensori yang sangat lemah dan skala 5 menunjukkan intensitas atribut sensori yang sangat kuat. Setelah selesai melakukan uji RATA, panelis yang sama diminta melakukan uji hedonik yang bertujuan untuk mengetahui penerimaan panelis terhadap sampel (Ngamchuachit et al., 2015). Panelis diminta untuk memberikan rating berupa penilaian tingkat kesukaan keseluruhan (overall) dari buah mangga gedong dan gedong gincu.

\section{Karakterisasi komponen volatil buah mangga gedong dan gedong gincu (San et al., 2017) \\ Analisis komponen volatil buah mangga gedong dan gedong gincu pada penelitian ini bertujuan untuk mendapatkan komponen volatil yang hanya terdapat pada buah mangga gedong, komponen volatil yang hanya terdapat pada buah mangga ge-}


dong gincu, serta komponen volatil yang mengalami perubahan konsentrasi pada buah mangga gedong dan buah mangga gedong gincu.

Tabel 1. Atribut sensori dan deskripsinya dalam uji rate-all-that-apply (RATA)

\begin{tabular}{|c|c|c|}
\hline No. & Atribut Sensori & Deskripsi \\
\hline \multicolumn{3}{|c|}{ Penampakan } \\
\hline 1 & Warna & $\begin{array}{l}\text { Warna daging buah kuning } \\
\text { hingga kuning kemerahan }\end{array}$ \\
\hline 2 & Berserat & $\begin{array}{l}\text { Terlihat serat/serabut pada } \\
\text { permukaan buah }\end{array}$ \\
\hline \multicolumn{3}{|c|}{ Aroma } \\
\hline 1 & Fruity & $\begin{array}{l}\text { Aroma khas buah mangga } \\
\text { gedong gincu matang }\end{array}$ \\
\hline 2 & Jambu & $\begin{array}{l}\text { Aroma manis yang khas buah } \\
\text { jambu matang }\end{array}$ \\
\hline 3 & Jeruk & $\begin{array}{l}\text { Aroma agak asam seperti } \\
\text { sitrus, khas buah jeruk }\end{array}$ \\
\hline 4 & Nanas & $\begin{array}{l}\text { Aroma manis, sedikit tajam, } \\
\text { khas buah nanas }\end{array}$ \\
\hline 5 & Karamel & Aroma khas karamel \\
\hline 6 & $\begin{array}{l}\text { Aroma masak } \\
\text { (cooked) }\end{array}$ & Aroma seperti buah dimasak \\
\hline 7 & Green & $\begin{array}{l}\text { Aroma agak asam seperti } \\
\text { buah belum matang }\end{array}$ \\
\hline 8 & Fermented & $\begin{array}{l}\text { Aroma kombinasi dari aroma } \\
\text { manis, buah terlalu matang, } \\
\text { dan sedikit asam }\end{array}$ \\
\hline 9 & Floral & Aroma manis seperti bunga \\
\hline 10 & Musty & Aroma seperti jamur segar \\
\hline 11 & $\begin{array}{l}\text { Aroma manis } \\
\text { (sweet) }\end{array}$ & Aroma seperti gula, madu \\
\hline \multicolumn{3}{|c|}{ Rasa } \\
\hline 1 & Manis & Rasa seperti larutan sukrosa \\
\hline 2 & Pahit & Rasa seperti larutan kafein \\
\hline 3 & Asam & $\begin{array}{l}\text { Rasa seperti larutan asam } \\
\text { sitrat }\end{array}$ \\
\hline \multicolumn{3}{|c|}{ Tekstur } \\
\hline 1 & Melting & $\begin{array}{l}\text { Kemudahan penekanan po- } \\
\text { tongan mangga ke bagian } \\
\text { atas mulut dengan lidah }\end{array}$ \\
\hline 2 & Firmness & $\begin{array}{l}\text { Energi yang dibutuhkan untuk } \\
\text { menekan sampel diantara li- } \\
\text { dah dan langit-langit mulut }\end{array}$ \\
\hline 3 & Chewiness & Kemudahan sampel ditelan \\
\hline 4 & Juiciness & $\begin{array}{l}\text { Jumlah cairan yang dilepas- } \\
\text { kan dari sampel selama gigit- } \\
\text { an pertama }\end{array}$ \\
\hline 5 & Fibrousness & $\begin{array}{l}\text { Keberadaan serat didalam } \\
\text { rongga mulut }\end{array}$ \\
\hline \multicolumn{3}{|c|}{ Aftertaste (sisa rasa) } \\
\hline 1 & Astringency & $\begin{array}{l}\text { Sensasi kering-berkerut pada } \\
\text { permukaan lidah }\end{array}$ \\
\hline 2 & Starchy & Sensasi bertepung \\
\hline
\end{tabular}

Keterangan: Ledeker et al. (2014)

Analisis komponen volatil dari buah mangga dilakukan menggunakan headspace solid-phase microextraction (SPME) (San et al., 2017). Sebanyak $2,5 \mathrm{~g}$ pure buah mangga gedong dan 2,5 g pure buah mangga gedong gincu diekstrak menggunakan
3 lapisan serat SPME: $100 \mu \mathrm{m}$ PDMS, $65 \mu \mathrm{m}$ PDMS/DVB, 50/30 $\mu \mathrm{m}$ DVB/CAR/PDMS (Supelco Park, Bellefonte, PA, USA). Ekstraksi SPME dilakukan pada suhu $40^{\circ} \mathrm{C}$ dengan penambahan $1 \mathrm{~g} \mathrm{NaCl}$ yang ditempatkan dalam $15 \mathrm{~mL}$ vial (Merck, Australia) yang dibungkus menggunakan PTFE-lined screw cap. Pengadukan dilakukan hingga ekstrak menjadi homogen. Waktu ekstraksi adalah selama 30 menit. Hasil ekstraksi dianalisis menggunakan Gas Chromatography-Mass Spectrometry (Agilent 7890A GC-MS, Agilent Technologies, USA) dilengkapi dengan Agilent Technologies 7693 Autosampler dan dipasangkan ke $5975 \mathrm{C}$ inert XL E1/C1 MSD dengan Triple Axis Detector) dengan metode injeksi splitless, yaitu gas pembawa mengangkut seluruh sampel ke dalam kolom. Suhu injeksi diatur pada $260^{\circ} \mathrm{C}$. Kolom yang digunakan adalah DBFFAP dengan diameter dalam $0,25 \mathrm{~mm}$, panjang 30 $\mathrm{m}$, dan ketebalan $0,25 \mu \mathrm{m}$. 1,4-dichlorobenzene digunakan sebagai internal standar dan n-alkana $\left(\mathrm{C}_{9}{ }^{-}\right.$ $\mathrm{C}_{22}$ ) digunakan sebagai standar Gas Chromatography-Mass Spectrometry (GC-MS). Helium digunakan sebagai gas pembawa dengan kecepatan 1 $\mathrm{mL} /$ menit. Komponen volatil dari buah mangga yang terdeteksi ditampilkan sebagai peak (puncak) kromatogram. Analisis komponen volatil dilakukan dengan membandingkan pola spektra massa komponen buah mangga dengan pola spektra massa komponen yang sama pada mass spectra library National Institute Standard and Technology 14 (NIST14). Selanjutnya prediksi dari konsentrasi komponen volatil dalam buah mangga dihitung dengan persamaan sebagai berikut:

Prediksi Konsentrasi Komponen Volatil $(\mathrm{ppb})=$

luas area B $\times$ jumlah $\mathrm{SI}$

B adalah komponen volatil terdeteksi GC-MS. SI adalah standar internal (1,4-dichlorobenzene).

\section{Analisis data}

Analisis data karakteristik fisikokimia dan intensitas sensori dari buah mangga gedong dan gedong gincu dilakukan dengan menggunakan dependent $t$-test/paired sample $t$-test (uji T-berpasangan) (XLSTAT 16) yang bertujuan untuk membandingkan nilai rata-rata dari dua seri sampel yang terkait.

\section{HASIL DAN PEMBAHASAN}

\section{Karakteristik fisikokimia buah mangga gedong dan gedong gincu}

Tabel 2 menunjukkan ciri fisik dari buah mangga gedong dan gedong gincu yang digunakan pada penelitian ini. Buah mangga gedong dipanen saat 
mencapai 88 hari setelah bunga mekar (HSBM) dan buah mangga gedong gincu dipanen saat umur buah 110 hari (HSBM). Waktu panen ini sesuai dengan standar operasional prosedur mangga gedong gincu off season (diluar musim) yang menyebutkan bahwa buah mangga gedong gincu yang belum matang memiliki umur buah $<108$ hari sedangkan buah mangga gedong gincu yang telah matang memiliki umur buah 108-120 hari (Disperta, 2016).

Tabel 2. Ciri fisik sampel buah mangga, 4 hari setelah pemanenan

\begin{tabular}{|c|c|c|}
\hline Ciri Fisik & Gedong & Gedong Gincu \\
\hline $\begin{array}{l}\text { Umur buah } \\
\text { (HSBM) }\end{array}$ & 88 & 110 \\
\hline Bentuk buah & Bulat & Bulat \\
\hline $\begin{array}{l}\text { Warna kulit } \\
\text { buah }\end{array}$ & Hijau & $\begin{array}{l}\text { Kuning, terdapat } \\
\text { bercak kemerahan }\end{array}$ \\
\hline $\begin{array}{l}\text { Warna daging } \\
\text { buah }\end{array}$ & Kuning muda & Kuning tua \\
\hline Berat (g) & $222,30 \pm 0,01$ & $259,09 \pm 0,01$ \\
\hline
\end{tabular}

Tabel 3 menunjukkan nilai $\mathrm{pH}$, total asam tertitrasi, total padatan, rasio gula-asam, dan firmness dari buah mangga gedong dan gedong gincu. Peningkatan nilai $\mathrm{pH}$ pada buah mangga gedong gincu diduga berhubungan dengan kandungan asam organik dalam buah yang mengalami ionisasi saat proses pematangan. Zainal et al. (2017) melaporkan bahwa pada proses pematangan buah, terjadi peningkatan kandungan air yang menyebabkan asam organik dalam buah terionisasi membentuk ion hidronium $\left(\mathrm{H}_{3} \mathrm{O}^{+}\right)$. Nilai $\mathrm{pH}$ dihitung sebagai negatif log dari konsentrasi ion hidronium bebas $\left(\mathrm{H}_{3} \mathrm{O}^{+}\right)$. Peningkatan ion hidronium bebas $\left(\mathrm{H}_{3} \mathrm{O}^{+}\right)$pada buah mangga gedong gincu menyebabkan semakin tingginya nilai $\mathrm{pH}$ yang terukur pada buah tersebut.

Kandungan asam terlarut pada buah mangga gedong lebih tinggi daripada gedong gincu. BatistaSilva et al. (2018) menyatakan bahwa buah mangga menunjukkan peningkatan respirasi pada saat dimulainya proses ripening (pemasakan buah). Pada proses respirasi, terjadi dekarboksilasi asam malat dalam buah yang menurunkan kandungan asam organik (Etienne et al., 2013). Hal ini menyebabkan kandungan asam organik pada buah mangga gedong lebih tinggi daripada gedong gincu. Tingginya kandungan asam tertitrasi pada buah mangga gedong ini juga didukung oleh hasil profil sensori (Gambar 2).

Total padatan terlarut pada buah mangga gedong lebih rendah secara signifikan dibandingkan gedong gincu. Total padatan terlarut meningkat seiring dengan meningkatnya proses pematangan buah (Hossain et al., 2014). Hal ini karena pada proses pematangan buah terjadi hidrolisis pati. Pada saat buah mencapai maturity (kematangan) (17-20 minggu setelah penyerbukan), mulai terjadi hidrolisis pati secara cepat. Pati terhidrolisis menjadi gula sederhana, yaitu sukrosa, glukosa, dan fruktosa dengan bantuan enzim seperti $\alpha$-amilase. Jumlah total padatan terlarut juga memengaruhi profil sensori rasa manis pada buah mangga. Intensitas rasa manis dari buah mangga gedong lebih rendah secara signifikan dibandingkan dengan buah mangga gedong gincu (Gambar 2).

Rasio gula-asam dari buah mangga gedong $(0,23)$ lebih rendah dibandingkan buah mangga gedong gincu $(0,79)$. Asam organik yang terdapat pada buah berdaging lunak sebagian besar berasal dari proses respirasi. Sementara itu, proses akumulasi pati menentukan kandungan padatan terlarut $\left({ }^{\circ}\right.$ Brix) dari buah yang telah matang. Kandungan gula yang tercermin dalam total padatan terlarut ( $\left.{ }^{\circ} B r i x\right)$ meningkat sebagai hasil dari konversi karbohidrat menjadi gula sederhana selama proses pematangan. Konversi karbohidrat ini menjadi parameter penting bagi proses pematangan pada buah mangga dan buah klimakterik lainnya. Hal ini menyebabkan rasio dari ${ }^{\circ}$ Brix/asam sering digunakan sebagai indeks tingkat kematangan.

Daging buah mangga gedong $(14,73 \pm 0,11)$ lebih keras dibandingkan daging buah mangga gedong gincu $(17,46 \pm 0,48)$ (Tabel 3$)$. Yannam et al. (2014) menyatakan bahwa pada saat buah mangga gedong memasuki proses pematangan, terjadi degradasi enzimatis pada struktur dinding sel yang menyebabkan pelunakan daging buah. Pektin pada dinding sel tanaman mengalami konversi menjadi soluble pectin oleh enzim poligalakturonase (PG) (Zheng et al., 2014). Soluble pectin ini menyebabkan melemahnya ikatan antar dinding sel, sehingga tekstur buah menjadi lunak. Pelunakan daging buah mangga gedong gincu juga dapat dilihat pada profil sensori buah mangga pada atribut firmness (kukuh, teguh), melting (daya leleh), dan juiciness (berair).

Tabel 3. Nilai $\mathrm{pH}$, total asam tertitrasi, total padatan, rasio gula-asam dan firmness buah mangga gedong dan gedong gincu, 4 hari setelah pemanenan

\begin{tabular}{cccccc}
\hline Sampel & $\mathrm{pH}$ & $\begin{array}{c}\text { Total Asam } \\
\text { Tertitrasi }(\%)\end{array}$ & $\begin{array}{c}\text { Total Padatan } \\
\text { ( }{ }^{\circ} \text { Brix) }\end{array}$ & $\begin{array}{c}\text { Rasio Gula } \\
\text { Asam }\end{array}$ & $\begin{array}{c}\text { Tekstur (Firmness, } \\
\text { mm) }\end{array}$ \\
\hline Gedong & $4,51 \pm 0,14$ & $17,89 \pm 3,66$ & $4,17 \pm 0,29^{*}$ & $0,24 \pm 0,05$ & $14,73 \pm 0,11$ \\
Gedong gincu & $4,81 \pm 0,31$ & $9,44 \pm 1,26$ & $7,50 \pm 0,00^{*}$ & $0,80 \pm 0,12$ & $17,46 \pm 0,48$ \\
\hline Ken
\end{tabular}

Keterangan: Angka yang diikuti oleh tanda bintang $\left(^{*}\right)$ menunjukkan berbeda nyata antar buah mangga pada taraf $5 \%$ dengan uji paired $t$-test. Nilai yang ditampilkan dalam tabel adalah nilai rata-rata dari tiga kali ulangan 


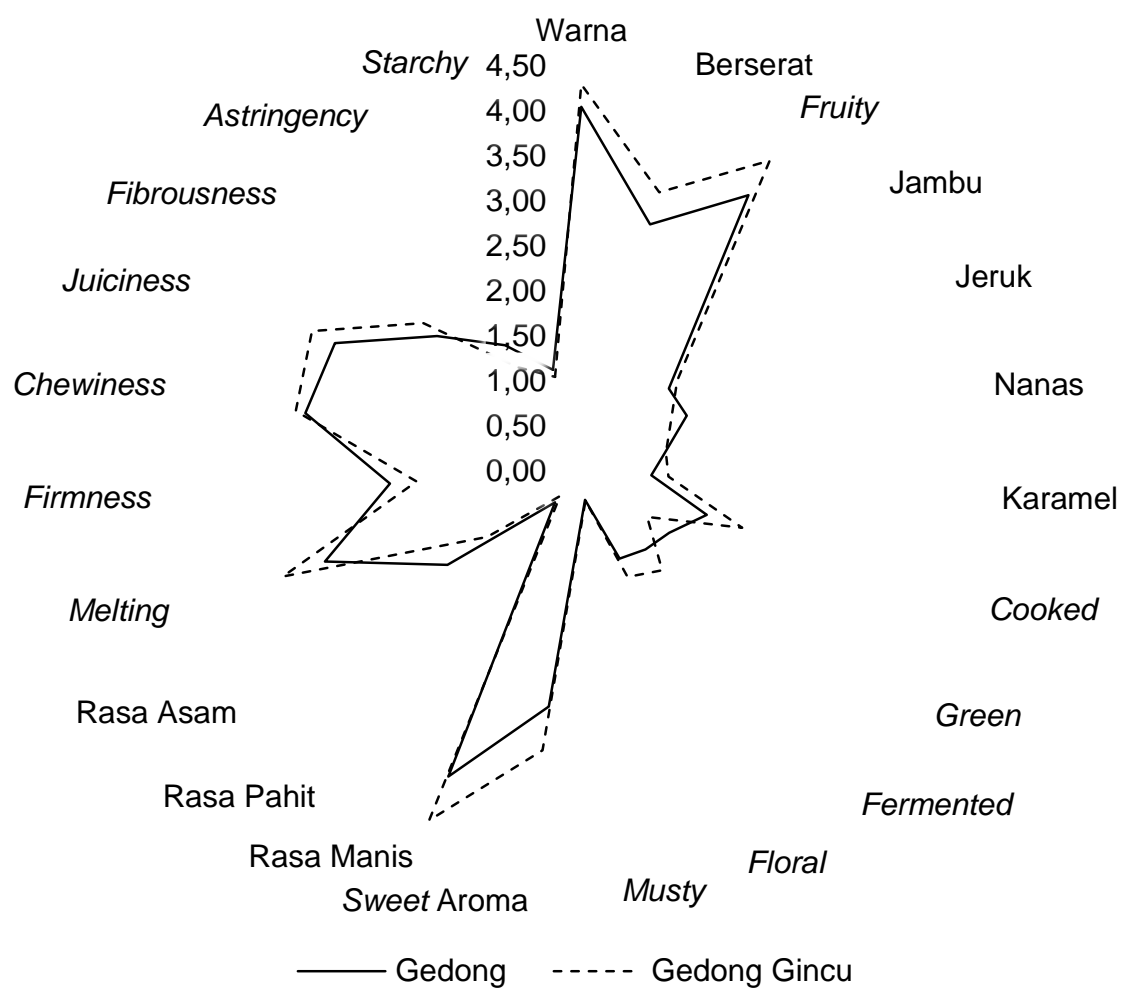

Gambar 2. Atribut sensori buah mangga gedong dan gedong gincu, 6 hari setelah panen

Tabel 4 menunjukkan nilai L, a, b dan ${ }^{\circ} \mathrm{Hue}$ dari daging buah dan kulit buah mangga gedong dan gedong gincu. Daging buah mangga gedong memiliki tingkat kecerahan lebih tinggi, intensitas warna merah lebih rendah, serta lebih berwarna kuning dibandingkan gedong gincu. Deskripsi warna daging buah gedong yaitu yellow red (kuning kemerahan) sedangkan gedong gincu memiliki deskripsi warna red (merah). Hal ini sesuai dengan intensitas atribut sensori warna yang menunjukkan bahwa daging buah mangga gedong memiliki warna kuning sedangkan daging buah mangga gedong gincu memiliki warna kuning kemerahan. Warna daging buah mangga gedong gincu yang lebih pekat disebabkan oleh peningkatan konsentrasi karotenoid ( $\beta$-karoten dan lutein) pada proses pematangan buah (Christ dan Hortensteiner, 2013).

Kulit buah mangga gedong memiliki tingkat kecerahan, intensitas warna merah dan kuning yang lebih rendah dibandingkan buah mangga gedong gincu. Deskripsi warna kulit buah mangga gedong dan gedong gincu adalah yellow red (kuning kemerahan). Berdasarkan diagram warna $L, a, b$, nilai derajat warna dari gedong gincu memiliki intensitas warna yellow red (kuning kemerahan) yang mendekati warna red (merah), dibandingkan dengan nilai derajat warna gedong. Pada proses pematangan buah mangga, terjadi peningkatan produksi etilen yang menyebabkan warna kulit buah menjadi lebih terang (Doke et al., 2018). Zhang et al. (2018) menyatakan bahwa kandungan klorofil pada kulit buah berkurang selama proses pematangan yang menyebabkan pigmen karotenoid menjadi lebih terlihat. Hal inilah yang menyebabkan kulit buah mangga gedong yang berwana hijau menjadi berwarna kuning kemerahan.

\section{Profil sensori citarasa buah mangga gedong dan gedong gincu}

Gambar 2 menunjukkan intensitas atribut sensori yang berkontribusi pada buah mangga gedong dan gedong gincu. Profil sensori buah mangga gedong berbeda dengan profil sensori buah mangga gedong gincu, yaitu pada warna, berserat, aroma lemony (aroma buah-buahan), caramel (aroma karamel), cooked (aroma buah matang), green (aroma buah mentah), fermented (aroma terfermentasi), floral (aroma bunga), sweet (aroma manis), rasa manis, rasa asam, melting (daya leleh), firmness (kukuh, teguh), juiciness (berair), dan astringency (sensasi sepat).

Intensitas atribut sensori rasa manis pada buah mangga gedong $(3,71 \pm 0,10)$ lebih rendah dibandingkan dengan gedong gincu $(4,23 \pm 0,10)$ (Tabel 5). Intensitas rasa manis ini didukung oleh hasil total padatan terlarut pada buah mangga. Total padatan terlarut pada buah mangga gedong lebih rendah dibandingkan buah mangga gedong gincu. Rasa buah mangga gedong gincu yang lebih manis diduga disebabkan oleh akumulasi gula sederhana yang disintesis secara aktif selama proses pematangan buah (Batista-Silva et al., 2018). 
Tabel 4. Warna daging buah mangga gedong dan gedong gincu, 4 hari setelah panen

\begin{tabular}{|c|c|c|c|c|c|c|}
\hline & $\mathrm{L}$ & $a$ & $b$ & ${ }^{\circ} \mathrm{Hue}$ & $\mathrm{C}$ & Warna \\
\hline \multicolumn{7}{|l|}{ Kulit Buah } \\
\hline Gedong & $48,16 \pm 0,28$ & $3,25 \pm 0,25$ & $20,28 \pm 0,78$ & $81,10 \pm 0,56$ & $20,58 \pm 1,30$ & Yellow red \\
\hline Gedong gincu & $51,88 \pm 0,30$ & $11,84 \pm 0,83^{\star}$ & $25,33 \pm 0,42^{*}$ & $65,35 \pm 1,73^{\star}$ & $28,14 \pm 0,86$ & Yellow red \\
\hline \multicolumn{7}{|l|}{ Daging Buah } \\
\hline $\begin{array}{l}\text { Gedong } \\
\text { Gedong gincu }\end{array}$ & $\begin{array}{l}74,15 \pm 0,73 \\
46,99 \pm 0,40\end{array}$ & $\begin{array}{c}3,03 \pm 0,01 \\
17,83 \pm 0,67^{*}\end{array}$ & $\begin{array}{l}39,63 \pm 0,07 \\
23,08 \pm 0,89\end{array}$ & $\begin{array}{l}85,64 \pm 0,01 \\
52,54 \pm 2,10\end{array}$ & $\begin{array}{l}39,77 \pm 0,07 \\
29,28 \pm 2,75\end{array}$ & $\begin{array}{c}\text { Yellow red } \\
\text { Red }\end{array}$ \\
\hline
\end{tabular}

Keterangan: Angka yang diikuti oleh tanda bintang $\left(^{*}\right)$ menunjukkan berbeda nyata antar buah mangga pada taraf $5 \%$ dengan uji paired t-test. Nilai yang ditampilkan dalam tabel adalah nilai rata-rata dari tiga kali ulangan

Tabel 5. Intensitas atribut sensori buah mangga gedong dan gedong gincu, 6 hari setelah panen

\begin{tabular}{|c|c|c|c|}
\hline \multirow{2}{*}{ Atribut Sensori } & \multicolumn{2}{|c|}{ Rataan } & \multirow{2}{*}{$P$ Value } \\
\hline & Gedong & Gedong gincu & \\
\hline \multicolumn{4}{|l|}{ Penampakan } \\
\hline Warna & $4,04 \pm 0,08$ & $4,28 \pm 0,08$ & $0,01^{*}$ \\
\hline Berserat & $2,83 \pm 0,12$ & $3,23 \pm 0,12$ & $0,00^{*}$ \\
\hline \multicolumn{4}{|l|}{ Aroma } \\
\hline Fruity (aroma buah-buahan) & $3,62 \pm 0,12$ & $4,07 \pm 0,12$ & $0,00^{*}$ \\
\hline Guava (aroma buah jambu) & $1,34 \pm 0,14$ & $1,48 \pm 0,14$ & 0,30 \\
\hline Orange (aroma buah jeruk) & $1,33 \pm 0,13$ & $1,13 \pm 0,13$ & 0,12 \\
\hline Pineapple (aroma buah nanas) & $0,96 \pm 0,12$ & $0,97 \pm 0,12$ & 0,92 \\
\hline Caramel (aroma karamel) & $0,75 \pm 0,13$ & $0,98 \pm 0,13$ & $0,04^{*}$ \\
\hline Cooked (aroma buah matang) & $1,50 \pm 0,18$ & $1,87 \pm 0,18$ & $0,02^{*}$ \\
\hline Green (aroma buah mentah) & $1,21 \pm 0,11$ & $0,91 \pm 0,11$ & $0,01^{*}$ \\
\hline Fermented (aroma terfermentasi) & $1,14 \pm 0,15$ & $1,44 \pm 0,15$ & $0,02^{*}$ \\
\hline Floral (aroma bunga) & $1,08 \pm 0,14$ & $1,30 \pm 0,14$ & $0,05^{\star}$ \\
\hline Musty (aroma jamur segar) & $0,33 \pm 0,07$ & $0,34 \pm 0,07$ & 0,90 \\
\hline Sweet (aroma manis) & $2,68 \pm 0,15$ & $3,12 \pm 0,15$ & $0,01^{*}$ \\
\hline \multicolumn{4}{|l|}{ Rasa } \\
\hline Manis & $3,71 \pm 0,10$ & $4,23 \pm 0,10$ & $0,00^{*}$ \\
\hline Pahit & $0,47 \pm 0,08$ & $0,37 \pm 0,08$ & 0,37 \\
\hline Asam & $1,84 \pm 0,13$ & $1,29 \pm 0,13$ & $0,00^{*}$ \\
\hline \multicolumn{4}{|l|}{ Tekstur } \\
\hline Melting (daya leleh) & $3,05 \pm 0,14$ & $3,56 \pm 0,14$ & $0,00^{*}$ \\
\hline Firmness (kukuh, teguh) & $2,15 \pm 0,12$ & $1,85 \pm 0,12$ & $0,01^{*}$ \\
\hline Chewiness (kelekatan) & $3,16 \pm 0,15$ & $3,27 \pm 0,15$ & 0,36 \\
\hline Juiciness (berair) & $3,08 \pm 0,12$ & $3,36 \pm 0,12$ & $0,02^{*}$ \\
\hline Fibrousness (berserat) & $2,21 \pm 0,15$ & $2,42 \pm 0,15$ & 0,27 \\
\hline \multicolumn{4}{|l|}{ Aftertaste } \\
\hline Astringency (sensasi sepat) & $1,65 \pm 0,15$ & $1,35 \pm 0,15$ & $0,03^{*}$ \\
\hline Starchy (sensasi bertepung) & $1,14 \pm 0,13$ & $1,05 \pm 0,13$ & 0,51 \\
\hline
\end{tabular}

Intensitas atribut sensori aroma sweet (aroma manis) pada buah mangga gedong lebih rendah dibandingkan buah mangga gedong gincu. Hal ini didukung oleh komponen volatil yang ditemukan pada buah mangga gedong gincu yang didominasi oleh komponen beraroma sweet (aroma manis). Berdasarkan hasil analisis komponen volatil yang terdeteksi pada buah mangga gedong gincu, komponen volatil yang memiliki aroma sweet (aroma manis) yaitu etil 2,4-heksadienoat, 4-etil-o-silena. (Tabel 6).

Intensitas atribut sensori aroma fruity (buahbuahan), aroma caramel (karamel), aroma cooked (buah matang), aroma green (buah mentah), aroma fermented (terfermentasi), aroma floral (bunga) pada buah mangga gedong lebih rendah dibandingkan buah mangga gedong gincu. Fenomena yang sejalan dengan hasil karakterisasi komponen volatil yang menunjukkan bahwa buah mangga gedong gincu didominasi oleh komponen beraroma fruity (buah-buahan) dan floral (bunga), yaitu komponen 3-caren, etil butirat, butil asetat, heksil asetat, serta etil heptanoat (Tabel 6).

Intensitas atribut sensori aroma green (aroma buah mentah) pada buah mangga gedong lebih tinggi $(1,21 \pm 0,11)$ dibandingkan gedong gincu $(0,91 \pm$ 0,11 ) (Tabel 5). Hal ini didukung dengan hasil analisis komponen volatil yang menunjukkan bahwa komponen volatil beraroma green (aroma buah mentah) lebih banyak terdeteksi pada buah mangga gedong daripada gedong gincu. 
Tabel 6. Komponen volatil yang hanya ditemukan pada buah mangga gedong atau gedong gincu, 10 hari setelah panen

\begin{tabular}{|c|c|c|c|c|c|}
\hline \multirow{2}{*}{ No } & \multirow{2}{*}{ Nama Komponen Volatil ${ }^{a}$} & \multicolumn{2}{|c|}{ Prediksi Konsentrasi (ppb) } & \multirow{2}{*}{$\begin{array}{c}\text { Ambang Deteksi } \\
\text { Bau (ppb) }\end{array}$} & \multirow{2}{*}{ Deskripsi Aroma $^{b}$} \\
\hline & & Gedong & Gedong Gincu & & \\
\hline & Alkohol & & & & \\
\hline 1 & 1-heksanol & 81.880 & - & $500^{[2]}$ & Fatty, green, grass \\
\hline \multirow[t]{2}{*}{2} & trans-2-heksenol & 33.420 & - & $100^{[1]}$ & Green \\
\hline & Monoterpen & & & & \\
\hline 3 & $\beta$-siklositral & 58.970 & - & $5^{[4]}$ & Fruity, green \\
\hline 4 & trans-geranil aseton & 81.010 & - & $60^{[4]}$ & Fresh, green \\
\hline 5 & Iso-terpinolen & 16.580 & - & $200^{[4]}$ & Herbal \\
\hline 6 & $\beta$-tujen & - & 2.061 .060 & $22^{\lfloor b]}$ & Woody \\
\hline 7 & $\beta$-pinen-(1S)-(-) & - & 3.210 .380 & $140^{[2]}$ & Pine \\
\hline \multirow[t]{2}{*}{8} & 3 -caren & - & 58.240 & $770^{[2]}$ & Citrus fruit \\
\hline & Seskuiterpen & & & & \\
\hline 9 & Selina-3,7(11)-dien & 80.010 & - & $68^{[4]}$ & Herbal, woody \\
\hline 10 & Iso-kariofilen & - & 384.310 & $64^{[3]}$ & Woody \\
\hline 11 & Eremofilen & - & 1.788 .920 & $68^{[4]}$ & Terpeny \\
\hline \multirow[t]{2}{*}{12} & $\beta$-humulen & - & 38.150 & $390^{[1]}$ & Woody \\
\hline & Aldehida & & & & \\
\hline 13 & Heksanal & 146.380 & - & $4,50^{\lfloor 2,3]}$ & Fatty, grass, green \\
\hline 14 & 2-heksenal, (E)- & 1.022 .590 & - & 240 & Green \\
\hline \multirow[t]{2}{*}{15} & Dekanal & - & 49.150 & $0,10^{[3]}$ & Soapy \\
\hline & Keton & & & & \\
\hline \multirow[t]{2}{*}{16} & Asetoin & - & 64.390 & $8.000^{[3]}$ & Buttery \\
\hline & Ester & & & & \\
\hline 17 & cis-3-heksen-1-ol, asetat & 873.980 & - & $50^{[4]}$ & Green \\
\hline 18 & cis-3-heksenil butirat & 375.150 & - & $470^{[1]}$ & Green \\
\hline 19 & $\begin{array}{l}\text { Asam 2-butenoat, 3- } \\
\text { heksenil ester, }(E, Z)-\end{array}$ & 98.310 & - & $320^{[4\rfloor}$ & Fresh, green \\
\hline 20 & $\alpha-$ etil butanoat & - & 77.910 & $1^{[3]}$ & Fruity \\
\hline 21 & Etil butirat & - & 1.818 .760 & $18^{[4]}$ & Fruity (pineapple) \\
\hline 22 & Butil asetat & - & 1.587 .580 & $66^{[3]}$ & Fruity \\
\hline 23 & Heksil asetat & - & 93.930 & $2^{[4]}$ & Fruity \\
\hline 24 & Etil heptanoat & - & 52.990 & $2^{[3]}$ & Fruity \\
\hline \multirow[t]{2}{*}{25} & Etil 2,4-heksadienoat & - & 32.010 & $300^{[5]}$ & Sweet, fruity \\
\hline & Benzena & & & & \\
\hline 26 & 4-etil-o-silena & - & 71.430 & $380-470^{[6]}$ & Sweet \\
\hline
\end{tabular}

Keterangan: ${ }^{a}$ Hasil identifikasi mass spectra dengan data referensi dari Library; ${ }^{\circ}$ Deskripsi aroma berdasarkan referensi yang melaporkan komponen volatil yang ditemukan pada buah mangga; ${ }^{[1]}$ Tamura et al. (2001); ${ }^{[2]}$ Bonneau et al. (2016); ${ }^{[3]}$ Pino (2012); ${ }^{[4]}$ Leffingwell (2008); ${ }^{[5]}$ Pino et al. (2012); ${ }^{[6]}$ Wang et al. (2016).

Komponen volatil yang memiliki aroma green (aroma buah mentah) pada buah mangga gedong yaitu 1-heksanol, trans-2-heksenol, $\beta$-siklositral, trans-geranilaseton, heksanal, 2-heksenal, (E)-, cis3-heksen-1-ol, asetat, cis-3-heksenil butirat, serta asam 2-butenoat, 3-heksenil ester, (E,Z)- (Tabel 6).

Analisis sensori warna dengan parameter angka yang lebih rendah menunjukkan warna kuning sedangkan angka yang lebih tinggi menunjukkan warna kuning kemerahan. Gambar 2 menunjukkan bahwa nilai warna buah mangga gedong lebih rendah dari warna buah gedong gincu. Hal ini berarti bahwa gedong gincu memiliki warna daging buah kuning kemerahan. Hasil ini didukung oleh analisis warna yang menunjukkan bahwa daging buah gedong memiliki dominasi warna kuning.

Intensitas atribut sensori melting (daya leleh) dan juiciness (berair) pada buah mangga gedong lebih rendah dibandingkan gedong gincu. Sementara itu, intensitas atribut sensori firmness (kukuh, teguh) pada buah mangga gedong lebih tinggi daripada pada buah mangga gedong gincu. Atribut sensori ini diduga berhubungan dengan hasil pengukuran firmness (kukuh, teguh) daging buah mangga menggunakan penetrometer yang menunjukkan bahwa daging buah mangga gedong lebih keras dibandingkan daging buah mangga gedong gincu. $\mathrm{Hal}$ ini diduga karena pada proses pematangan buah mangga terjadi pelemahan ikatan antara dinding sel buah sehingga tekstur buah menjadi lunak (Yannam et al., 2014).

Secara keseluruhan (overall), tingkat penerimaan terhadap buah mangga gedong $(5,37 \pm 0,09 ; 5=$ agak suka) lebih rendah secara signifikan dibanding buah mangga gedong gincu $(6,20 \pm 0,09 ; 6=$ suka). Hadayanti et al. (2016) menyatakan bahwa buah 
mangga gedong gincu disukai oleh konsumen dan memiliki permintaan pasar yang tinggi meskipun harga jualnya termasuk tinggi.

Komponen volatil pemberi aroma yang ditemukan hanya pada buah mangga gedong atau gedong gincu (Tabel 6). Komponen volatil yang hanya ditemukan pada buah mangga gedong sebagian besar merupakan komponen volatil yang memiliki deskripsi aroma green (aroma buah mentah), fresh (aroma segar) dan grass (aroma rerumputan) (Gambar 3). Di sisi lain, komponen volatil yang hanya ditemukan pada buah mangga gedong gincu didominasi oleh komponen volatil yang memiliki deskripsi aroma fruity (aroma buah-buahan), floral (aroma bunga), sweet (aroma manis), dan woody (aroma kayukayuan) (Gambar 4). Fenomena yang menunjang karakteristik sensori kedua mangga.

Komponen volatil heksanal (Lebrun et al., 2008); $\beta$-siklositral, trans-geranilaseton, iso-terpinolen (Lalel et al., 2003) dilaporkan banyak terdapat pada buah mangga mentah. Hal ini sejalan dengan profil sensori buah mangga gedong yang memiliki tingkat kematangan yang lebih rendah dibandingkan buah mangga gedong gincu didominasi oleh kompo- nen volatil tipe ini. Keberadaan senyawa volatil dengan deskripsi aroma green (aroma buah mentah), fresh (aroma segar) dan grass (aroma rerumputan) dapat menjelaskan karakteristik sensori dari buah mangga gedong, yaitu atribut aroma green (aroma segar) lebih dominan pada buah mangga gedong dibandingkan buah mangga gedong gincu.

Senyawa ester, antara lain a-etil butanoat, etil butirat, butil asetat, heksil asetat, etil heptanoat, etil 2,4-heksadienoat, yang memiliki deskripsi aroma fruity (aroma buah-buahan) dan sweet (aroma manis) diduga menjadi kontributor yang menyebabkan perbedaan intensitas sensori fruity (aroma buahbuahan), aroma karamel, cooked (aroma buah matang), floral (aroma bunga), sweet (aroma manis) pada buah mangga gedong gincu (Lalel et al., 2003) (Gambar 2).White et al. (2016) menyatakan bahwa komponen ester merupakan komponen dominan yang dihasilkan oleh buah mangga yang telah matang. Pada sel tumbuhan, reaksi pemecahan asam lemak melalui jalur $\beta$-oksidasi maupun lipoksigenase dapat menghasilkan komponen aroma (El Hadi et al., 2013).

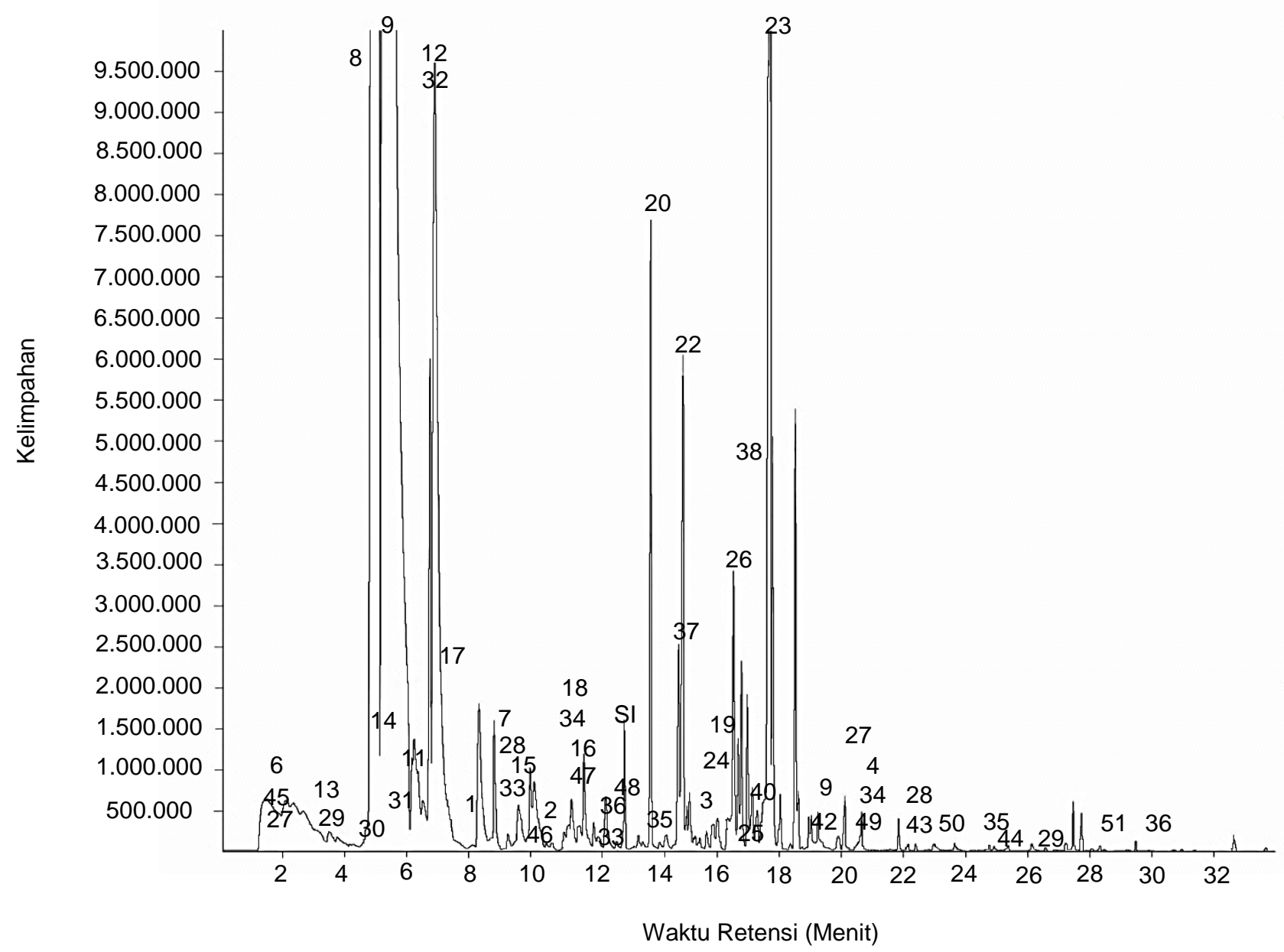

Gambar 3. Profil kromatogram komponen volatil buah mangga gedong melalui ekstraksi SPME 


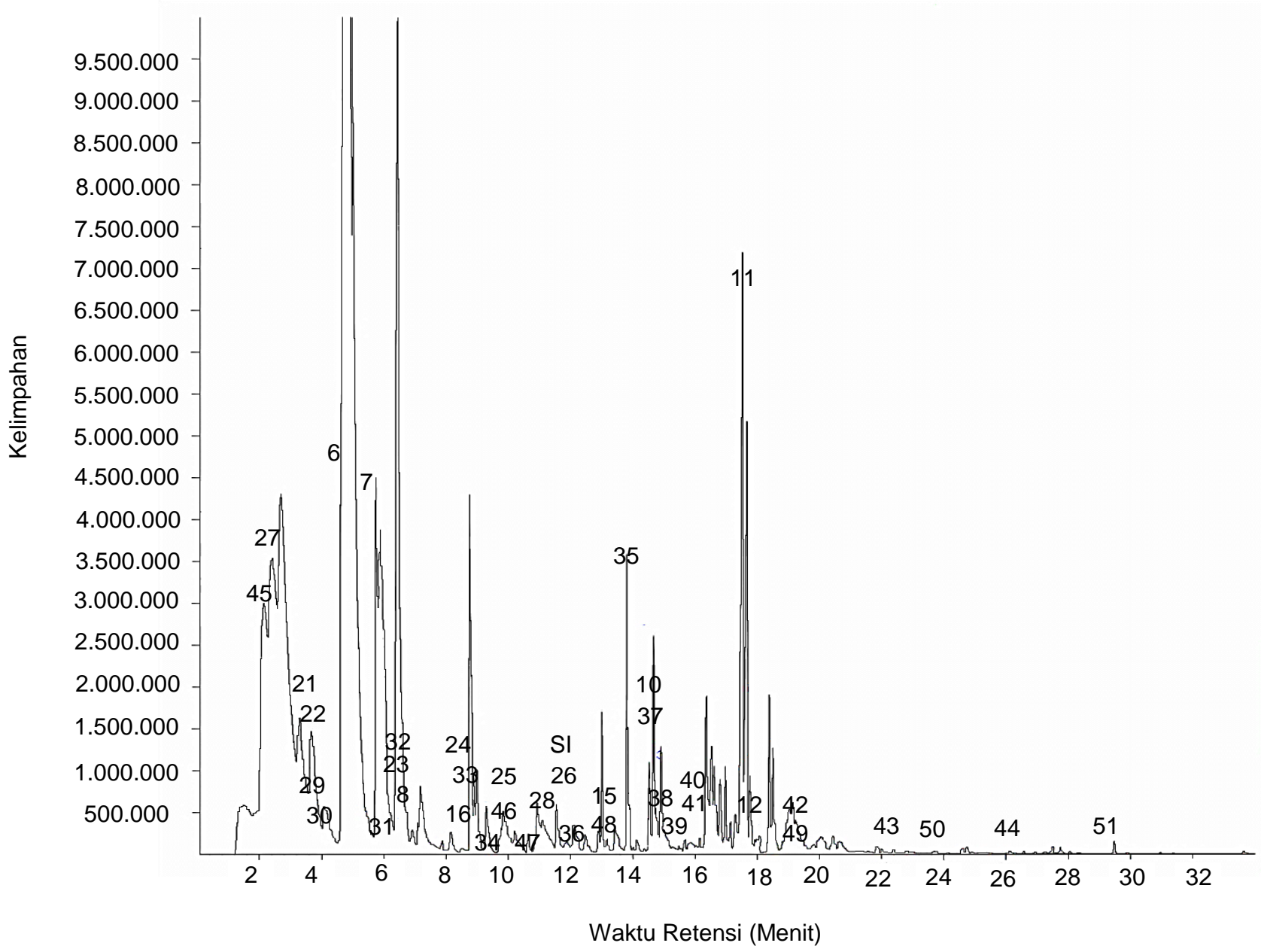

Gambar 4. Profil kromatogram komponen volatil buah mangga gedong gincu melalui ekstraksi SPME

Etil butirat, butil asetat, serta etil asetat menjadi komponen ester dominan pada buah mangga gedong gincu. Tingkat kematangan buah mangga gedong gincu juga dapat terlihat dengan terdeteksinya 3-caren, dekanal, $\beta$-pinen-(1S)-(-) yang dilaporkan oleh Lebrun et al. (2008) dan Lalel et al. (2003) yang menyatakan bahwa komponen volatil tersebut teridentifikasi pada buah mangga matang.

Tabel 7 menunjukkan komponen volatil yang ditemukan pada buah mangga gedong dan buah mangga gedong gincu. Komponen volatil $\beta$-pinen, 1,3,8-p-menta triena, cis-linalool oksida, kariofilen, $\beta$-selinen, D-germakrena, serta etil sorbat meningkat jumlahnya pada buah mangga gedong dan menurun pada buah mangga gedong gincu. Berdasarkan penelitian sebelumnya, komponen volatil $\beta$-pinen, kariofilen, $\beta$-mirsen, cis-3-heksenol, humulen (Lebrun et al., 2008) dilaporkan lebih banyak terdapat pada buah mangga mentah dan berkurang jumlahnya seiring dengan pematangan buah mangga. Komponen volatil etanol, $\beta$-osimen, trans-kalamenen, etil asetat, n-butil tiglat, etil kaprilat, serta etil laurat jumlahnya meningkat seiring matangnya buah mangga. Berdasarkan penelitian sebelumnya, komponen volatil $\beta$-osimen, $\alpha$-kopaen, $\delta$-kadinen (Lalel et al., 2003) lebih tinggi pada buah mangga matang dibandingkan dengan pada buah mangga mentah.

Buah mangga gedong gincu memiliki penampakan fisik yang lebih menarik dibandingkan dengan buah mangga arumanis dan cengkir. Keunggulan penampakan fisik pada buah mangga gedong gincu menjadikan buah mangga ini lebih digemari oleh konsumen. Pathare et al. (2013) menyatakan bahwa kualitas dari bahan pangan yang dapat memberikan informasi penting untuk dipilih oleh konsumen yaitu kualitas penampakan berupa warna, ukuran, serta tekstur. Selain penampakan fisik yang menarik, buah mangga gedong gincu juga memiliki atribut sensori aroma yang kuat dan khas. Atribut sensori aroma dari buah mangga gedong gincu terdiri dari berbagai komponen volatil yang memiliki deskripsi aroma fruity (aroma buah-buahan), caramel (aroma karamel), cooked (aroma buah matang), fermented (aroma terfermentasi), floral (aroma bunga) dan sweet (aroma manis). 
Tabel 7. Komponen volatil yang ditemukan pada buah mangga gedong dan gedong gincu, 10 hari setelah panen

\begin{tabular}{|c|c|c|c|c|c|}
\hline \multirow{2}{*}{ No } & \multirow{2}{*}{ Nama Komponen Volatil ${ }^{a}$} & \multicolumn{2}{|c|}{ Prediksi Konsentrasi (ppb) } & \multirow{2}{*}{$\begin{array}{c}\text { Ambang Deteksi } \\
\text { Bau (ppb) }\end{array}$} & \multirow{2}{*}{ Deskripsi Aroma $^{b}$} \\
\hline & & Gedong & Gedong Gincu & & \\
\hline & Alkohol & & & & \\
\hline 27 & Etanol & 518.660 & 3.882 .850 & $100.000^{[3]}$ & Vinous, ethereal \\
\hline \multirow[t]{2}{*}{28} & cis-3-heksenol & 254.830 & 126.280 & $70^{[3]}$ & Floral \\
\hline & Monoterpen & & & & \\
\hline 29 & $\beta$-mirsen & 4.376 .150 & 23.951 .240 & $15^{[2]}$ & Woody, resinous \\
\hline 30 & $\beta$-pinen & 41.060 .900 & 6.709 .440 & $140-1.500^{[1,2]}$ & Green \\
\hline 31 & $\beta$-osimen & 322.180 & 5.483 .830 & $34^{[2]}$ & Sweet \\
\hline 32 & cis- $\beta$-osimen & 6.615 .330 & 521.150 & $34^{[2]}$ & Citrus, sweet \\
\hline 33 & Neo-allo-osimen & 354.090 & 287.040 & $34^{[1]}$ & Floral, citrus \\
\hline 34 & 1,3,8-p-menta triena & 242.910 & 6.250 & $6,80^{\lfloor b\rfloor}$ & Terpenic \\
\hline 35 & Linalool & 1.293 .100 & 805.770 & $1-6^{[1,3]}$ & Floral, citrus \\
\hline \multirow[t]{2}{*}{36} & cis-linalool oksida & 83.730 & 42.630 & $100^{[2]}$ & Fresh \\
\hline & Seskuiterpen & & & & \\
\hline 37 & Kariofilen & 1.377 .010 & 642.490 & $64-160^{[2,3]}$ & Green, terpenic \\
\hline 38 & $\beta$-selinen & 5.016 .820 & 160.340 & $980^{[1]}$ & Herbal \\
\hline 39 & $\alpha$-selinen & 64.220 & 27.400 & $93^{[1]}$ & Woody \\
\hline 40 & Valencene & 88.720 & 19.450 & $0,47^{[4]}$ & Citrus \\
\hline 41 & Humulen & 776.070 & 464.980 & $140-160^{\lfloor 1,3\rfloor}$ & Earthy, woody \\
\hline 42 & trans-kalamenen & 160.650 & 175.320 & $0.0025^{\lfloor 4\rfloor}$ & Clove, herbaceous \\
\hline 43 & trans- $\beta$-ionon & 68.130 & 65.410 & $0.0070^{[2]}$ & Woody \\
\hline \multirow[t]{2}{*}{44} & Germakrena-D & 5.580 & 4.620 & $19^{[1]}$ & Cut-grass like \\
\hline & Ester & & & & \\
\hline 45 & Etil asetat & 526.080 & 3.390 .940 & $3.300-5.000^{[1,3]}$ & Sweet, fruity \\
\hline 46 & n-butil tiglat & 35.580 & 86.290 & $2,90-6,70^{[6]}$ & Floral, herbaceous \\
\hline 47 & Etil kaprilat & 85.770 & 231.270 & $15^{[4]}$ & Waxy \\
\hline 48 & Etil sorbat & 44.510 & 10.940 & $560^{[1]}$ & Green \\
\hline 49 & Etil laurat & 10.330 & 71.700 & $3.500^{[/\rfloor}$ & Sweet, floral, fruity \\
\hline \multirow[t]{2}{*}{50} & Etil miristat & 18.870 & 5.210 & $2.000^{[4]}$ & Waxy \\
\hline & Fenol & & & & \\
\hline 51 & 2,4-di-tert-butil fenol & 10.840 & 30.930 & $5.900^{[4]}$ & - \\
\hline
\end{tabular}

Keterangan: ${ }^{a}$ Hasil identifikasi mass spectra dengan data referensi dari Library; ${ }^{\text {D}}$ Deskripsi aroma berdasarkan referensi yang melaporkan komponen volatil yang ditemukan pada buah mangga; ${ }^{[1]}$ Tamura et al. (2001); ${ }^{[2]}$ Bonneau et al. (2016); ${ }^{[3]}$ Pino (2012); ${ }^{[4]}$ Leffingwell (2008); ${ }^{[5]}$ Liu et al. (2020); ${ }^{[6]}$ Grondin et al. (2015); ${ }^{[7]}$ Welke et al. (2014)

Hadayanti et al. (2016) melaporkan bahwa konsumen di Kota Bandung, Jawa Barat memiliki tingkat kesukaan yang tinggi terhadap konsumsi buah mangga gedong gincu, diikuti oleh buah mangga arumanis dan cengkir. Hal ini menunjukkan keunggulan buah mangga gedong gincu dari segi penampakan fisik dan cita rasa.

Keunggulan cita rasa yang dimiliki oleh buah mangga gedong gincu memiliki potensi untuk dikembangkan, salah satunya melalui pemuliaan tanaman (breeding). Pemuliaan tanaman mangga dengan target modifikasi cita rasa khususnya pada komponen aroma menjadi penting guna mendapatkan progeni buah mangga yang memiliki warna buah dan komponen aroma menyerupai gedong gincu. Pemuliaan tanaman dengan target modifikasi komponen aroma nantinya dapat dilakukan dengan mengkawinsilangkan gen pembawa komponen aroma kunci dari buah mangga gedong gincu ke buah mangga varietas lain. Proses ini masih membutuh- kan pengetahuan dasar mengenai komponen aroma kunci dari buah mangga gedong gincu, jalur metabolisme pembentukan komponen aroma kunci tersebut, dan identifikasi gen pembawa komponen aroma kunci.Data profil flavor buah mangga hasil kajian penelitian ini diharapkan dapat menjadi landasan bagi pengembangan keilmuan ilmiah varietas buah mangga baru unggulan. Karakteristik fisikokimia, profil sensori, serta komponen volatil pembentuk buah mangga gedong dan gedong gincu dari hasil penelitian ini juga dapat digunakan sebagai informasi dasar kualitas buah mangga gedong dan gedong gincu yang diterima oleh konsumen bila buah dipanen saat mencapai tingkat kematangan half mature (setengah matang) dan full ripe (matang). Pemanenan buah mangga gedong ketika mencapai umur buah 88 hari dan gedong gincu saat mencapai umur buah 110 hari direkomendasikan untuk dilakukan. 


\section{KESIMPULAN}

Karakteristik fisikokimia serta profil sensori citarasa buah mangga gedong berbeda dengan gedong gincu. Buah mangga gedong memiliki nilai $\mathrm{pH}$, total padatan terlarut, dan nilai firmness (kukuh, teguh) yang lebih rendah dibandingkan gedong gincu. Total asam tertitrasi dari buah mangga gedong lebih tinggi daripada gedong gincu. Warna kulit buah mangga gedong memiliki tingkat kecerahan, intensitas warna merah dan kuning yang lebih rendah dibandingkan kulit buah mangga gedong gincu. Profil sensori citarasa buah mangga gedong memiliki perbedaan intensitas atribut yang lebih lemah dibandingkan buah mangga gedong gincu, yaitu pada atribut sensori warna, berserat, aroma fruity (aroma buah-buahan), caramel (aroma karamel), cooked (aroma buah matang), fermented (aroma terfermentasi), floral (aroma bunga) dan sweet (aroma manis), melting (daya leleh), firmness (kuku, teguh), juiciness (berair) dan astringency (sepat). Karakterisasi komponen volatil menunjukkan buah mangga gedong didominasi oleh komponen volatil yang beraroma green (aroma buah mentah), sedangkan buah mangga gedong gincu didominasi oleh komponen volatil yang beraroma fruity (aroma buahbuahan) dan sweet (aroma manis). Sensori buah mangga gedong gincu secara keseluruhan lebih disukai oleh panelis (skor hedonik 6,20 $\pm 0,09 ; 6=$ suka) dibandingkan dengan buah mangga gedong (skor hedonik 5,37 $\pm 0,09 ; 5=$ agak suka).

\section{UCAPAN TERIMA KASIH}

Terima kasih kepada LPPM IPB dan Kemenristek-Dikti yang telah mendanai penelitian ini melalui Program Penelitian Dasar Unggulan Perguruan Tinggi (PDUPT) Tahun Anggaran 2018 (No. 1740/ IT3.11/PN/2018).

\section{DAFTAR PUSTAKA}

[AOAC] Association of Official Analytical Chemists. 2012. Official Method 932.12. Solids (Soluble) in Fruits and Fruit Products. Chapter 37. 7. Official Methods of Analysis of AOAC International 19th ed, Volume II, Latimer, GW (Editor). AOAC International Maryland, USA.

[AOAC] Association of Official Analytical Chemists. 2012. Official Method 942.15. Acidity (Titratable) of Fruits Products. Chapter 37. 10. Official Methods of Analysis of AOAC International 19th ed, Volume II, Latimer, GW (Editor). AOAC International Maryland, USA.
Ares G, Bruzzone F, Vidal L, Cadena RS, Gimenez A, Pineau B, Hunter DC, Paisley AG, Jaeger SR. 2014. Evaluation of a rating-based variant of check-all-that-apply questions: Rate-all-thatapply (RATA). Food Qual Prefer 36: 87-95. DOI: 10.1016/j.foodqual.2014.03.006.

Batista-Silva WB, Nascimento VL, Medeiros DB, Nune-Nesi A, Ribeiro DM, Zsögön A, Araújo WL. 2018. Modifications in organic acid profiles during fruit development and ripening: Correlation or causation?. Front Plant Sci 9: 1-20. DOI: $10.3389 /$ fpls.2018.01689.

Bonneau A, Boulanger R, Lebrun M, Maraval I, Gunata Z. 2016. Aroma compounds in fresh and dried mango fruit (Mangifera indica $L$. Cv. Kent): Impact of drying on volatile composition. Int J Food Sci Tech 51: 789-800. DOI: 10.1111/ ijfs. 13038.

Christ B, Hörtensteiner S. 2013. Mechanism and significance of chlorophyll breakdown. J Plant Growth Regul 33: 4-20: DOI: 10.1007/s00344013-9392-y.

Disperta. 2016. Standar Operasional Prosedur Mangga Gedong Gincu Off Season Kabupaten Majalengka, Cirebon dan Indramayu. Pemerintah Provinsi Jawa Barat Dinas Pertanian Tanaman Pangan. Bandung.

Doke ND, Dhemre JK, Khalates SM. 2018. Role of ethylene on ripening of Kesar mango fruits. Int $\mathrm{J}$ Chem Stud 6: 170-174.

Etienne A, Génard M, Lobit P, Mbeguié-A-Mbéguié D, Bugaud C. 2013. What controls fleshy fruit acidity? A review of malate and citrate accumulation in fruit cells. J Exp Bot 64: 1451-1469. DOI: 10.1093/jxb/ert035.

Fahri N, Purwanto YA, Budiastra IW. 2016. Penggolongan mangga gedong gincu berdasarkan rasio kandungan gula asam menggunakan prediksi near infrared spectroscopy. J Keteknikan Pertanian 4: 31-36. DOI: 10.19028/jtep.04.1.3136.

Grondin E, Sing ASC, Caro Y, Billerbeck GMD, François JM, Petit T. 2015. Physiological and biochemical characteristics of the ethyl tiglate production pathway in the yeast Saprochaete suaveolens. Yeast 32: 57-66.

Hadayanti D, Deliana Y, Natawidjaja RS. 2016. Faktor dominan dari preferensi konsumen dalam pemilihan jenis mangga (Mangifera indica): Suatu kasus di supermarket di kota Bandung. J Agrikultura 27: 94-101. DOI: 10.24198/agrikul tura.v27i2.9989.

El Hadi MAM, Zhang F-J, Wu F-F, Zhou C-H, Tao J. 2013. Advances in fruit aroma volatile research: 
Molecules 18: 8200-8229. DOI: 10.3390/molecu les18078200.

Hossain MdA, Rana MdM, Kimura Y, Roslan HA. 2014. Changes in biochemical characteristics and activities of ripening associated enzymes in mango fruit during the storage at different temperatures. Biomed Res Int 2014: 1-11. DOI: 10. 1155/2014/232969.

Leffingwell \& Associates. 2008. Odor \& flavor detection thresholds in water (in parts per billion). http://www.leffingwell.com/odorthre.htm [21 Januari 2020].

Lalel HJD, Singh Z, Tan SC. 2003. Aroma volatiles production during fruit ripening of 'Kensington Pride' mango. Postharvest Biol Tec 27: 323336. DOI: 10.1016/S0925-5214(02)00117-5.

Lebrun M, Plotto A, Goodner K, Ducamp MN, Baldwin E. 2008. Discrimination of mango fruit maturity by volatiles using the electronic nose and gas chromatography. Postharvest Biol Tec 48: 122-131. DOI: 10.1016/j.postharvbio.2007.0 9.010 .

Ledeker CN, Suwonsichon S, Chambers DH, Adhikari K. 2014. Comparison of sensory attributes in fresh mangoes and heat-treated mango purées prepared from Thai cultivars. LWT-Food Sci Technol 56: 138-144. DOI: 10.1016/j.Iwt. 2013.11.011.

Li L, Ma XW, Zhan RL, Wu HX, Yao QS, Xu WT, Luo C, Zhou YG, Liang QZ, Wang SB. 2017. Profiling of volatile fragrant components in a mini-core collection of mango germplasms from seven countries. PLoS One 12: 1-14. DOI: 10.1371/journal.pone.0187487.

Liu H, An K, Su S, Yu Y, Wu J, Xiao G, Xu Y. 2020. Aromatic characterization of mangoes (Mangifera indica L.) using solid phase extraction coupled with gas chromatography-mass spectrometry and olfactometry and sensory analyses. Foods 9: 1-20. DOI: 10.3390/foods 90100 75.

Munafo JP, Didzbalis J, Schnell RJ, Schieberle P, Steinhaus M. 2014. Characterization of the major aroma-active compounds in mango (Mangifera indica L.) cultivars haden, white alfonso, praya sowoy, royal special, and malindi by application of a comparative aroma extract dilution analysis. J Agric Food Chem 62: 45444551. DOI: $10.1021 / \mathrm{jf5} 508743$.

Nassur RCMR, González-Moscoso S, Crisosto GM, Lima LCO, Boas EVB, Crisosto CH. 2015. Describing quality and sensory attributes of 3 mango (Mangifera indica L.) cultivars at 3 ripeness stages based on firmness. J Food Sci 80: S2055-S2063. DOI: 10.1111/1750-3841.12 989.
Ngamchuachit P, Sivertsen HK, Mitcham EJ, Barrett DM. 2015. Influence of cultivar and ripeness stage at the time of fresh-cut processing on instrumental and sensory qualities of fresh-cut mangos. Postharvest Biol Tech 106: 11-20. DOI: 10.1016/j.postharvbio.2015.03.013.

Pathare PB, Opara UL, AI-Said FA. 2013. Colour measurement and analysis in fresh and processed foods-a review. Food Bioproc Tech 6: 36-60. DOI: 10.1007/s11947-012-0867-9.

Pino JA. 2012. Odour-active compounds in mango (Mangifera indica L. cv. Corazón). Int J Food Sci Tech 47: 1944-1950. DOI: 10.1111/j.13652621.2012.03054.x.

Pino JA, Quijano CE. 2012. Study of the volatile compounds from plum (Prunus domestica L. cv. Horvin) and estimation of their contribution to the fruit aroma. Food Sci Technol 32: 76-83. DOI: 10.1590/S0101-20612012005000006.

San AT, Joyce DC, Hofman PJ, Macnish AJ, Webb $\mathrm{RI}$, Matovic NJ, Williams CM, De Voss JJ, Wong SH, Smyths HE. 2017. Stable isotope dilution assay (SIDA) and HS-SPME-GCMS quantification of key aroma volatiles for fruit and sap of Australian mango cultivars. Food Chem 221: 613-619. DOI: 10.1016/j.foodchem.2016. 11.130.

Sari HP, Purwanto YA, Budiastra IW. 2016. Pendugaan kandungan kimia mangga gedong gincu menggunakan spektroskopi inframerah dekat. Agritech 36: 294-301. DOI: 10.22146/agritech. 16599.

Siriamornpun S, Kaewseejan N. 2017. Quality, bioactive compounds and antioxidant capacity of selected climacteric fruits with relation to their maturity. Sci Hortic-Amsterdam 221: 33-42. DOI: 10.1016/j.scienta.2017.04.020

Tamura H, Boonbumrung S, Yoshizawa T, Varanyanond W. 2001. The volatile constituents in the peel and pulp of a green Thai mango, Khieo Sawoei cultivar (Mangifera indica L.). Food Sci Technol Res 7: 72-77. DOI: 10.3136/fstr.7.72.

Wang L-B, Bai J, Yu Z-F. 2016. Difference in volatile profile between pericarp tissue and locular gel in tomato fruit. J Integr Agric 15: 2911-2920. DOI: 10.1016/S2095-3119(15)61324-7.

Welke JE, Zanus M, Lazzarotto M, Zini CA. 2014. Quantitative analysis of headspace volatile compounds using comprehensive two-dimensional gas chromatography and their contribution to the aroma of Chardonnay wine. Food Res Int 59: 85-99. DOI: 10.1016/j.foodres.2014. 02.002 .

White IR, Blake RS, Taylor AJ, Monks PS. 2016. Metabolite profiling of the ripening of mangoes 
Mangifera indica L. cv. 'Tommy Atkins' by realtime measurement of volatile organic compounds. Metabolomics 12: 1-11. DOI: 10.1007/ s11306-016-0973-1.

Yannam SK, Shetty PR, Obulum VSR. 2014. Optimization, purification and characterization of polygalacturonase from mango peel waste produced by Aspergillus foetidus. Food Technol Biotechnol 52: 359-367.

Zainal PW, Purwanto AY, Ahmad U. 2017. Identifikasi gejala chilling injury berdasarkan perubahan $\mathrm{pH}$ dan ion leakage pada buah mangga gedong gincu. J Teknologi Pertanian Andalas 21: 16-21. DOI: 10.25077/jtpa.21.1.16-21.2017.
Zhang J-Y, Pan D-L, Jia Z-H, Wang T, Wang G, Guo Z-R. 2018. Chlorophyll, carotenoid and vitamin $\mathrm{C}$ metabolism regulation in Actinidia chinensis 'Hongyang' outer pericarp during fruit development. PLoS One 13: 1-17. DOI: 10.1371/ journal.pone.0194835.

Zheng X, Jing G, Liu Y, Jiang T, Jiang Y, Li J. 2012. Expression of expansin gene, MiExpA1, and activity of galactosidase and polygalacturonase in mango fruit as affected by oxalic acid during storage at room temperature. Food Chem 132: 849-854. DOI: 10.1016/j.foodchem.2011.11.0 49. 